\title{
TELAAH PENERAPAN SISTEM INFORMASI MANAJEMEN PADA BADAN AMIL ZAKAT INFAQ DAN SHADAQOH
}

\author{
Oleh: \\ Nur Hisamuddin \\ Dosen Universitas Negeri Jember \\ Hi5am@yahoo.com
}

\begin{abstract}
Indonesia has great potential zakat due predominantly Muslim. Based on the study Baznas potential zakat fund is expected to reach 217 trillion. The amount of zakat fund management requires good management, transparency and accountability. The number of transactions and the amount of assets under management makes information management system ZIS an important part in the management process. However, the constraints of the application of management information system ZIS common in zakat management institutions. Sharia enterprise theory states that people should take responsibility for his actions not only in the world but also in the hereafter. The information system is a system to help accountability. Accounting information system is an information system that contains data or components of both physical and non-physical that interact are then processed to produce useful information for the parties concerned.
\end{abstract}

Keywords: information management system, ZIS, Accounting information system

\section{A. PENDAHULUAN}

Indonesia merupakan negara dengan jumlah penduduk muslim terbesar di |Dunia. Dengan jumlah penduduk mencapai 300 juta lebih, penganut agama islam memiliki porsi $88,1 \%$. Hampir di setiap daerah penduduk muslim tersebar dan dapat hidup rukun dengan pemeluk agama lain. Mereka bekerja pada berbagai bidang, mulai dari pengusaha, pejabat, guru, petani, nelayan dan lain-lain. (BPS, 2010).

Muslim memiliki beberapa kewajiban yang harus dipatuhi dan dilaksanakan, salah satunya adalah zakat. Zakat 
merupakan bagian dari rukun islam yang ketiga dan hukumnya adalah wajib bagi setiap muslim yang telah mencapai nisab. Zakat merupakan amalan untuk mensucikan manusia. Perintah zakat tertuang dalam QS. Attaubah : 103.

Orang yang membayar zakat disebut muzakki sedangkan yang menerima disebut sebagai mustahiq. Mustahiq sendiri dibagi menjadi delapan golongan, yaitu : Fakir, Miskin, Ghorim, Sabilillah, Ibnu Sabil, Muallaf, Hamba Sahaya (Budak) dan Amil. Amil adalah orang yang mengelola zakat, yaitu menerima dan menyalurkan zakat. Amil menurut syariat, seharusnya berbentuk lembaga yang disahkan oleh pemerintah. Hal ini untuk mengatur agar pengelaolaan zakat menjadi lebih baik.

Undang-Undang Nomor 23 tahun 2011 menjelaskan bahwa pengelolaan zakat adalah kegiatan perencanaan, pelaksanaan, dan pengoordinasian dalam pengumpulan, pendistribusian, dan pendayagunaan zakat. Berdasarkan pasal 1 keputusan Menteri Agama Nomor 581 tahun 1999, mendefinisikan Badan Amil Zakat adalah organisasi pengelola zakat yang dibentuk pemerintah terdiri atas unsur masyarakat dan pemerintah dengan tugas mengumpulkan, mendistribusikan, dan mendayagunakan zakat sesuai ketentuan agama.

Baznas saat ini telah memiliki perwakilan hingga ke masing-masing kota yang ada di Indonesia. Selain berfungsi sebagai pengelola zakat, Baznas juga berfungsi melakukan koordinasi dengan lembaga-lembaga pengelola zakat agar pengelolaan zakat dapat efektif, efisien dan akuntabel

Besarnya jumlah penduduk muslim dan wajibnya hukum melaksanakan zakat, menjadikan Indonesia sebagai Negara dengan jumlah potensi zakat yang besar. Dalam prediksi BAZNAS pada tahun 2017, total dana zakat yang mestinya dapat dikumpulkan adalah sebesar 217 triliyun rupiah. Tetapi dari jumlah sebesar itu, hanya 4,7 triliyun saja yang menjadi target Baznas pada tahun 2017. 


\section{Nur Hisamuddin}

Potensi zakat yang sedemikian besar menuntut pengelolaan yang professional, baik dari sisi SDM maupun Organisasi. Dana Zakat tidak hanya berhenti pada penerimaan dan penyaluran zakat saja, tetapi harus ada bentuk pertanggung jawaban seperti laporan keuangan yang akan menjadi jembatan informasi bagi semua pihak yang berkepentingan. Beberapa pengguna informasi yang terkait dengan lembaga zakat antara lain adalah muzakki, pemerintah, manajemen amil, masyarakat umum, mustahiq.

Jumlah muzakki dan mustahiq yang mencapai ribuan sexara nasional memunculkan ratusan bahkan ribuan transaksi yang harus diolah setiap hari. Pengguna Informasi juga menuntut penyediaan informasi secara cepat dan tepat serta dapat dipertanggung jawabkan. Kondisi ini untuk lembaga sebesar Baznas jelas menuntut penggunaan sistem informasi daripada mengandalkan proses manual.

Sistem informasi sebagai alat untuk mempermudah pengelolaan informasi karenanya menjadi bagian penting sebab data yang dikelola sedemikian besar dan tuntutan yang tinggi dari para pihak pengguna informasi atas transparansi dan kredibilitas lembaga zakat. Sistem informasi ini dapat berupa program/software apapun yang diharapkan akan menghasilkan informasi yang sesuai dengan kebutuhan pengguna informasi dan dapat dipertanggung jawabkan. Karenanya Baznas saat ini telah menerapkan system pengelolaanya pada SIMBAZNAS. Pengelolaan zakat bertujuan meningkatkan manfaat zakat untuk mewujudkan kesejahteraan masyarakat dan penanggulangan kemiskinan (Yulinartati, Roziq, dan Lely: 2012)

Penelitian Yulinartati, Roziq, Norita, dan Wahyu (2013) menganalisis penerapan sistem informasi manajemen pada LAZIZMU di Kabupaten Jember. Penelitian ini menyatakan bahwa terdapat peningkatan positif persepsi muzaki terhadap laporan keuangan dari hasil penerapan model dan sistem informasi. Muzakki menyatakan adanya manfaat dari penyajian laporan keuangan. Muzakki juga menganggap adanya sistem 
informasi memberikan banyak informasi penting yang berguna bagi muzakki.

\section{B. Pembahasan}

\section{Akuntansi Syariah}

Akuntansi syariah (Triyuwono, 2012:337): sebagai proses akuntansi yang menyediakan informasi yang tepat/sesuai (yang tidak dibatasi pada data keuangan) kepada stakeholders dari suatu entitas yang akan memungkinkan mereka untuk menyakinkan bahwa entitas beroperasi secara kontinyu dalam ikatan syari'ah Islam dan mengantarkan pada tujuan falah, yaitu mencapai kebahagian dunia-akherat, kesejahteraan materi-spiritual. Triyuwono (2012:6-7) berpendapat bahwa akuntansi syari'ah masih dalam tataran teoritis-filosofis. Sehingga untuk membentuk laporan keuangan akuntansi syari'ah harusnya didasarkan pada teori akuntansi yang digali dari ajaran/syari'ah Islam yang bersumber pada Al-Qur'an dan Hadits.

Perintah mencatat transaksi (akuntansi) dalam Al-Quran terdapat dalam surat Al-Baqarah ayat 282 :

Artinya: "Hai orang-orang yang beriman, apabila kamu bermu'amalah tidak secara tunai untuk waktu yang ditentukan, hendaklah kamu menuliskannya. dan hendaklah seorang penulis di antara kamu menuliskannya dengan benar. dan janganlah penulis enggan menuliskannya sebagaimana Allah mengajarkannya, maka hendaklah ia menulis, dan hendaklah orang yang berhutang itu mengimlakkan (apa yang akan ditulis itu), dan hendaklah ia bertakwa kepada Allah Tuhannya, dan janganlah ia mengurangi sedikitpun daripada hutangnya. jika yang berhutang itu orang yang lemah akalnya atau lemah (keadaannya) atau dia sendiri tidak mampu mengimlakkan, maka hendaklah walinya mengimlakkan dengan jujur. dan persaksikanlah dengan dua orang saksi dari orang-orang lelaki (di antaramu). Jika tak ada dua oang lelaki, maka (boleh) seorang lelaki dan dua orang perempuan dari saksi-saksi yang kamu ridhai, supaya jika seorang lupa maka yang seorang 


\section{Nur Hisamuddin}

mengingatkannya. Janganlah saksi-saksi itu enggan (memberi keterangan) apabila mereka dipanggil; dan janganlah kamu jemu menulis hutang itu, baik kecil maupun besar sampai batas waktu membayarnya. yang demikian itu, lebih adil di sisi Allah dan lebih menguatkan persaksian dan lebih dekat kepada tidak (menimbulkan) keraguanmu. (tulislah mu'amalahmu itu), kecuali jika mu'amalah itu perdagangan tunai yang kamu jalankan di antara kamu, Maka tidak ada dosa bagi kamu, (jika) kamu tidak menulisnya. dan persaksikanlah apabila kamu berjual beli; dan janganlah penulis dan saksi saling sulit menyulitkan. jika kamu lakukan (yang demikian), maka sesungguhnya hal itu adalah suatu kefasikan pada dirimu. dan bertakwalah kepada Allah; Allah mengajarmu; dan Allah Maha mengetahui segala sesuatu" (Yayasan Penyelenggara/Penafsir Al-Quran: 2000).

Menurut Desy Andikawati (2014) akuntansi islam dan akuntansi konvensional pasti memiliki perbedaan karena keduanya memiliki dasar yang berbeda. Islam membawa wordview (pandangan) yang berasal dari Allah SWT. sedangkan kapitalis membawa wordview dari pemikiran manusia yang dikuasai oleh nafsu yang bisa saja dikendalikan oleh syetan. Jadi akuntansi syariah merupakan alat yang diharapkan dapat digunakan untuk mewujudkan sistem ekonomi islam yang adil, jujur, dan tidak ada pihak yang mengendalikan pihak lain, tidak merusak alam, akidah, dan ketentuan yang telah ditetapkan Allah SWT. Akuntansi islam (syariah) harus bisa menciptakan ekonomi yang adil dan islam yang rahmatan lil alamin.

\section{Enterprise Theory}

Teroi ini menyatakan bahwa manusia tidak hanya bertanggung jawab di dunia saja tetapi juga di akherat. Tujuan manusia diciptakan adalah untuk beribadah. Sehingga dalam pengelolaan keuangan, definisi terhadap pihak yang berkepentingan menjadi lebih luas. Alam semesta beserta isinya adalah pihak yang harus diperhatikan dalam pertanggung jawaban laporan keuangan. Menurut teori ini, manusia menjadi 
lebih jujur karena mereka bekerja seolah-olah selalu diawasi oleh tuhan Nya dan difahami sebagai ibadah. (Triyuwono, 2013)

\section{Pengelolaan Zakat}

Berdasarkan Undang-Undang Republik Indonesia Nomor 23 tahun 2011 tentang pengelolaan zakat, maka yang dimaksud "Pengelolaan Zakat" adalah kegiatan yang meliputi perencanaan, pengorganisasian, pelaksanaan, dan pengawasan terhadap pendistribusian serta pendayagunaan zakat. Dalam PSAK 109 terdapat pernyataan utama mengenai pengakuan, pengukuran, penyajian, dan pengungkapan atas dana zakat, infaq/shadaqoh, dan amil. Selain itu dijelaskan pula mengenai muzakki, mustahiq, dan organisasi pengelola zakat. Muzakki adalah individu muslim yang secara syariah wajib membayar (menunaikan) zakat. Mustahiq adalah orang atau entitas yang berhak menerima zakat. Mustahiq dikelompokkan menjadi delapan golongan atau asnaf, yaitu :

a. Fakir

b. Miskin

c. Amil

d. Orang yang baru masuk islam (muallaf)

e. Hamba sahaya

f. Orang yang terlilit hutang (ghorim)

g. Orang yang berada dijalan Allah (fisabilillah)

h. Orang yang sedang dalam perjalanan (ibnu sabil/musyafir)

Pembagian golongan diatas berdasarkan firman Allah dalam surat At-Taubah ayat 60 yang artinya :

"Sesungguhnya zakat-zakat itu hanyalah untuk orang-orang fakir, orang-orang miskin, pengurus-pengurus zakat, para mualaf yang dibujuk hatinya, untuk (memerdekakan) budak, orang-orang yang berhutang, untuk dijalan Allah, dan orang-orang yang sedang dalam perjalanan sebagai suatu ketetapan yang diwajibkan Allah. Dan Allah maha mengetahui lagi maha bijaksana" (Yayasan Penyelenggara/Penafsir Al-Quran: 2000).

Dalam PSAK 109 juga terdapat dana bergulir yaitu terdapat dalam paragraf 31: "Penyaluran infak/sedekah kepada penerima 


\section{Nur Hisamuddin}

akhir dalam skema dana bergulir dicatat sebagai piutang infak/sedekah bergulir dan tidak mengurangi dana infak/sedekah".

Undang-Undang Nomor 23 tahun 2011 menyebutkan prinsip-prinsip pengelolaan zakat, infaq, dan shodaqah sebagai berikut :

a. Pengelolaan zakat berasaskan :

1) Syariat Islam

2) Amanah

3) Kemanfaatan

4) Keadilan

5) Kepastian hukum

6) Terintegritas

7) Akuntabilitas

b. Pengelolaan zakat bertujuan :

1) Meningkatkan evektivitas dan efesiensi pelayanan dalam pengelolaan zakat.

2) Meningkatkan manfaat zakat untuk mewujudkan kesejahteraan masyarakat dan penanggulangan kemiskinan.

c. Ruang lingkup pengelolaan :

Pengelolaan zakat adalah kegiatan perencanaan, pelaksanaan, dan pengorganisasian dalam pengumpulan, pendistribusian, dan pendayagunaan zakat.

d. Kegiatan zakat meliputi pengumpulan, pendistribusian, dan pendayagunaan zakat.

OPZ harus memiliki sistem pengelolaan yang baik. Menurut Sucipto (2011) unsur-unsur yang harus diperhatikan adalah :

a) Memiliki Sistem, Prosedur, Danaturan Yang Jelas

Sebagai sebuah lembaga, sudah seharusnya jika semua kebijakan dan ketentuan dibuat aturan mainnya secara jelas dan tertulis. Sehingga keberlangsungan lembaga tidak tergantung kepada figur seseorang, tetapi kepada sistem. Jika terjadi pergantian SDM sekalipun, aktivitas lembaga tidak akan terganggu karenanya.

b) Manajemen Terbuka 
Karena OPZ tergolong lembaga publik, maka sudah selayaknya jika menerapkan manajemen terbuka. Maksudnya, ada hubungan timbal balik antara amil zakat selaku pengelola dengan masyarakat. Dengan ini maka akan terjadi sistem kontrol yang melibatkan unsur luar, yaitu masyarakat itu sendiri.

c) Mempunyai Rencana Kerja (Activity Plan)

Rencana kerja disusun berdasarkan kondisi lapangan dan kemampuan sumber daya lembaga. Dengan dimilikinya rencana kerja, maka aktivitas OPZ akan terarah. Bahkan dapat dikatakan, dengan dimilikinya rencana kerja yang baik, itu berarti 50\% target telah tercapai.

d) Memiliki Komite Penyaluran (Lending Committee)

Agar dana dapat tersalur kepada yang benar-benar berhak, maka harus ada suatu mekanisme sehingga tujuan tersebut dapat tercapai. Salah satunya adalah dibentuknya Komite Penyaluran. Tugas dari komite ini adalah melakukan penyeleksian terhadap setiap penyaluran dana yang akan dilakukan. Apakah dana benar-benar disalurkan kepada yang berhak, sesuai dengan ketentuan syariah, prioritas, dan kebijakan lembaga. Prioritas penyaluran perlu dilakukan. Hal ini tentunya berdasarkan survei lapangan, baik dari sisi asnaf mustahiq maupun bidang garapan (ekonomi, pendidikan, dakwah, kesehatan, sosial, dan lain sebagainya). Prioritas ini harus dilakukan karena adanya keterbatasan sumber daya dan dana dari lembaga.

a) Memiliki Sistem Akuntansi Dan Manajemen Keuangan Salah satu piranti yang dibutuhkan ialah model akuntansi yang mempunyai spesifikasi sesuai dengan operasional lembaga pengelola zakat yang berbeda dari akuntansi konvensional. Akuntansi zakat mempunyai kaidah-kaidah tersendiri yang tidak terdapat pada sistem akuntansi yang selama ini sudah ada.

b) Diaudit

Sebagai bagian dari penerapan prinsip transparansi, diauditnya OPZ sudah menjadi keniscayaan. Baik oleh 


\section{Nur Hisamuddin}

auditor internal maupun eksternal. Auditor internal diwakili oleh Komisi Pengawas atau internal auditor. Sedangkan auditor eksternal dapat diwakili oleh Kantor Akuntan Publik atau lembaga audit independen lainnya.

c) Publikasi

Semua yang telah dilakukan harus disampaikan kepada publik, sebagai bagian dari pertanggungjawaban dan transparannya pengelola. Caranya dapat melalui media massa seperti surat kabar, majalah, buletin, radio, TV, dikirim langsung kepada para donatur, atau ditempel di papan pengumuman yang ada di kantor OPZ yang bersangkutan. Hal-hal yang perlu dipublikasikan antara lain laporan keuangan, laporan kegiatan, nama-nama penerima bantuan, dan lain sebagainya.

d) Perbaikan Terus-Menerus (Continous Improvment)

Hal yang tidak boleh dilupakan adalah dilakukannya peningkatan dan perbaikan secara terus-menerus tanpa henti, karena dunia terus berubah.

\section{Sistem Informasi Akuntansi}

a. Definisi Sistem Informasi Akuntansi

Ada beberapa pengertian sistem informasi akuntansi menurut beberapa ahli, antara lain :

1) Menurut Bodnar \& Hopwood (2010) mengatakan bahwa yang dimaksud dengan sistem informasi akuntansi merupakan suatu kumpulan dari berbagai macam sumber daya, seperti manusia dan juga peralatan yang dirancang untuk mengubah data keuangan dan juga data lainnya menjadi sebuah informasi yang berguna bagi user atau penggunanya.

2) Menurut Mulyadi (2008) mengatakan bahwa suatu sistem informasi akuntansi merupakan suatu bentuk sistem informasi yang memiliki tujuan untuk menyediakan informasi bagi pengelola kegiatan usaha, memperbaiki informasi yang dihasilkan oleh sistem yang sudah ada sebelumnya, memperbaiki 
pengendalian akuntansi dan juga pengecekan internal, serta membantu memperbaiki biaya klerikal dalam pemeliharaan catatan akuntansi.

Berdasarkan beberapa pendapat tersebut, maka dapat disimpulkan bahwa sistem informasi akuntansi adalah suatu sistem informasi yang berisi data atau komponen baik fisik maupun non fisik yang saling berinteraksi yang kemudian diolah sedemikianrupa sehingga menghasilkan informasi yang berguna bagi pihak-pihak yang berkepentingan.

b. Tujuan Sistem Informasi Akuntansi

Menurut Susanto (2008:8-1), tujuan sistem informasi akuntansi adalah sebagai berikut :

1) Mendukung aktivitas perusahaan sehari-hari

2) Mendukung proses pengambilan keputusan

3) Membantu pengelolaan perusahaan dalam memenuhi tanggung jawabnya kepada pihak eksternal

4) Mengumpulkan dan memasukkan data transaksi ke dalam sistem informasi akuntansi

5) Mengolah data transaksi

6) Menyimpan data untuk tujuan di masa mendatang

7) Memberi pemakai atau pengambil keputusan (manajemen) informasi yang mereka perlukan

8) Mengontrol semua proses yang terjadi.

Menurut Behesti (2014), tujuan utama dari sistem informasi akuntansi ialah menyediakan informasi yang berguna bagi pihak-pihak yang berkepentingan sebagai dasar pengambilan keputusan. Pihak-pihak yang berkepentingan disini terdiri dari pihak internal (manajemen) dan pihak eksternal (investor, kreditor,dll.). Yang dimaksud dengan pihak internal, yaitu amil BAZ. Sedangkan pihak eksternal, yaitu seperti para muzakki, mustahiq, dan pemerintah. Informasi yang dihasilkan (outcome) tidak hanya berupa laporan keuangan, akan tetapi juga berupa daftar muzakki dan mustahiq, pendistribusian dana ZIS (Zakat, Infaq, Shadaqoh), serta data 


\section{Nur Hisamuddin}

pendukung lainnya yang digunakan sebagai dasar pengambilan keputusan.

\section{c. Komponen Sistem Informasi Akuntansi}

Komponen sistem informasi akuntansi terdiri dari beberapa bagian yang saling berintegrasi yang membentuk sebuah sistem. Menurut Susanto (2008:207) komponen sistem informasi akuntansi dapat dikelompokkan sebagai berikut :

1) Perangkat Keras (Hardware)

Hardware merupakan peralatan fisik yang dapat digunakan untuk mengumpulkan, memasukkan, memproses, menyimpan, dan mengeluarkan hasil pengolahan data dalam bentuk informasi.

2) Perangkat Lunak (Software)

Software adalah kumpulan dari progam-progam yang digunakan untuk menjalankan aplikasi tertentu pada komputer, sedangkan progam merupakan kumpulan dari perintah-perintah komputer yang tersusun secara sistematis.

3) Manusia (Brainware)

Brainware atau sumber daya manusia (SDM) merupakan bagian terpenting dari komponen sistem informasi dalam dunia bisnis yang dikenal sebagai sistem informasi akuntansi. Sumber daya manusia (SDM) sistem informasi akuntansi merupakan sumber daya yang terlibat dalam pembuatan sistem informasi, pengumpulan dan pengolahan data, pendistribusian dan pemanfaatan informasi yang dihasilkan oleh sistem informasi tersebut.

4) Prosedur (Procedure)

Prosedur merupakan rangkaian aktivitas atau kegiatan yang dilakukan secara berulang-ulang dengan cara yang sama. Sedangkan aktivitas pada dasarnya melakukan suatu kegiatan berdasarkan informasi yang masuk dan persepsi yang dimiliki tentang informasi.

5) Basis Data (Database) 
Database merupakan kumpulan data-data yang tersimpan didalam media penyimpanan di suatu perusahaan (arti luas) atau dalam komputer (arti sempit).

6) Teknologi Jaringan Komunikasi (Communication Network Technology)

Telekomunikasi atau komunikasi data dapat didefinisikan sebagai penggunaan media elektronik untuk memindahkan data atau informasi dari suatu lokasi ke satu atau beberapa lokasi lain yang berbeda. Komunikasi yang terjadi diantara beberapa pihak yang berkomunikasi harus difasilitasi dengan infrastruktur berupa jaringan telekomunikasi.

d. Tahapan Implementasi

Tahapan implementasi sistem menurut Anonim, terdiri dari lima tahapan, yaitu :

1) Pemrogaman dan pengujian

2) Instalasi perangkat keras dan perangkat lunak (Hardware dan Software)

3) Pelatihan kepada pemakai

4) Pembuatan dokumentasi

5) Konversi

Konversi sistem merupakan tahapan yang digunakan untuk mengoperasikan sistem baru dalam rangka menggantikan sistem yang lama atau proses pengubahan dari sistem lama ke sistem baru (Rahma, 2015). Ada empat metode untuk mengkonversi sistem, yaitu :

1) Konversi Langsung (Direct Conversion)

Konversi ini dilakukan dengan cara mengehentikan sistem lama dan menggantikannya dengan sistem baru. Cara ini merupakan yang paling berisiko, tetapi murah.

2) Konversi Paralel (Parallel Conversion)

Pada konversi ini, sistem baru dan sistem lama sama-sama dijalankan. Setelah melalui masa tertentu, jika sistem baru telah bisa diterima untuk menggantikan sistem lama, maka sistem lama segera dihentikan. Cara ini merupakan pendekatan yang paling aman, tetapi merupakan cara yang 


\section{Nur Hisamuddin}

paling mahal, karena pemakai harus menjalankan dua sistem sekaligus.

3) Konversi Bertahap (Phase-In Conversion)

Konversi dilakukan dengan menggantikan suatu bagian dari sistem lama dengan sistem baru. Jika terjadi sesuatu, bagian yang baru tersebut akan diganti kembali dengan yang lama. Jika tidak terjadi masalah, modul-modul baru akan dipasangkan lagi untuk mengganti modul-modul lama yang lain. Dengan pendekatan seperti ini, akhirnya semua sistem lama akan tergantikan oleh sistem baru.

4) Konversi Pilot (Pilot Conversion)

Pendekatan ini dilakukan dengan cara menerapkan sistem baru hanya pada lokasi tertentu yang diperlukan sebagai pelopor. Jika konversi ini dianggap berhasil, maka akan diperluas ke tempat-tempat lain. Ini merupakan pendekatan dengan biaya dan risiko rendah.

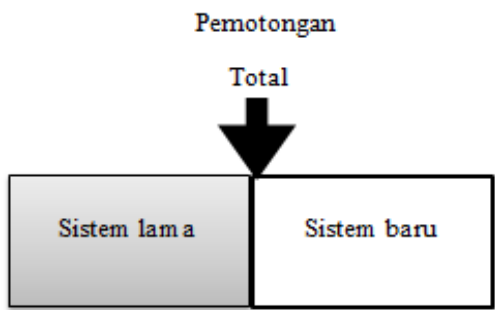

(Konversi Langsung)

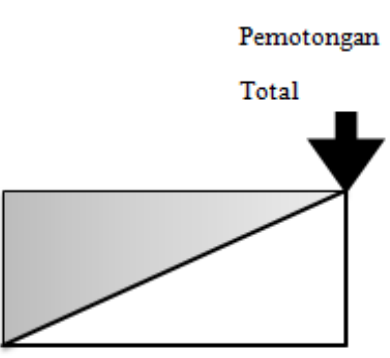

(Konversi Phase-In)

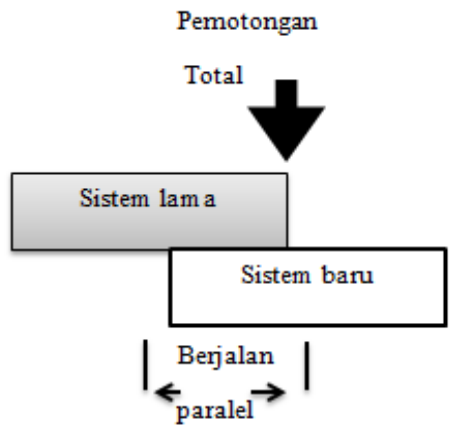

(Konversi Paralel)

Pemotongan

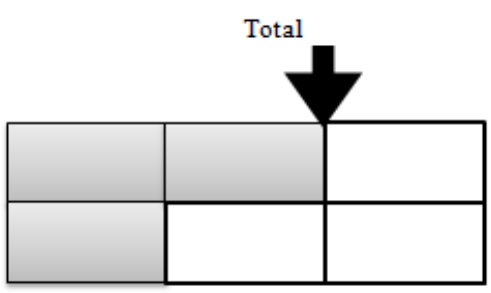

(Konversi Pilot)

Gambar 2.1 Representasi Grafik Metode Konversi Sistem (Sumber : Bodnar, 2006:45 


\section{Konsep Zakat, Infaq/Shadaqoh, dan Amil}

\section{a. Zakat}

Menurut PSAK 109 (IAI, 2008: paragraf 05), zakat adalah harta yang wajib dikeluarkan oleh muzakki sesuai dengan ketentuan syariah untuk diberikan kepada yang berhak menerimanya (mustahiq). Zakat adalah ibadah yang hukumnya wajib (fardhu a'in) bagi setiap muslim (umat Islam) dengan cara menyisihkan sebagian harta yang dimiliki yang sudah memenuhi nisab untuk diberikan kepada orang-orang yang berhak menerima sesuai ketentuan syariah. Orang yang membayar zakat disebut muzakki sedangkan orang yang menerima zakat disebut mustahiq. Nisab adalah batas minimum harta yang wajib dikeluarkan zakatnya. Perintah untuk melaksanakan zakat terdapat dalam Al-Quran surat Al-Baqarah ayat 43 yang artinya "Dirikanlah sholat, tunaikanlah zakat dan rukuklah kamu bersama orang-orang yang rukuk" (Yayasan Penyelenggara/Penafsir Al-Quran: 2000).

Zakat dibedakan menjadi dua jenis yaitu zakat fitrah dan zakat maal (Undang-Undang Nomor 23 tahun 2011). Zakat fitrah adalah zakat yang dibayarkan di bulan Ramadhan sebelum hari raya idul fitri atas kelebihan dari keperluan harian keluarga. Zakat ini bertujuan untuk mensucikan jiwa menjelang hari kemenangan umat Islam yaitu hari raya Idul Fitri. Cara melaksanakannya yaitu dengan memberikan sebagian makanan pokok sesuai nisab $(2,5 \mathrm{~kg})$ atau uang yang jumlahnya senilai untuk diberikan kepada mustakhiq. Sedangkan zakat maal adalah zakat yang dibayarkan atas kekayaan atau hasil usaha yang sudah mencapai nisab untuk diberikan kepada mustakhiq. Perintah mengenai zakat maal terdapat dalam AlQuran surat Al-Baqarah ayat 267 yang artinya :

"Hai orang-orang yang beriman, nafkahkanlah (dijalan Allah) sebagian dari hasil usahamu yang baol-baik, dan sebagian dari apa yang kamu keluarkan dari bumi untuk kamu. Dan janganlah kamu memilih yang buruk-buruk lalu kamu nafkahkan daripadanya, padahal kamu sendiri tidak mau mengambilnya melainkan dengan memicingkan mata terhadapnya, dan ketahuilah bahwa Allah Maha 


\section{Nur Hisamuddin}

kaya lagi Maha terpuji" (Yayasan Penyelenggara/Penafsir AlQuran: 2000).

\section{b. Infaq/Shadaqoh}

Menurtut PSAK 109, infak/sedekah adalah harta yang diberikan secara sukarela oleh pemiliknya, baik yang peruntukannya dibatasi (ditentukan) maupun tidak dibatasi. Perintah dan keutamaan berinfak/sedekah termaktub dalam Al-quran dan Hadits sebagai berikut :

"Dan belanjakanlah (hartamu) di jalan Allah, dan janganlah kamu menjatuhkan dirimu sendiri kedalam kebinasaan, dan berbuat baiklah, karena sesungguhnya Allah menyukai orang-orang yang berbuat baik". (Q.S Al-Baqrah: 195) (Yayasan Penyelenggara/Penafsir Al-Quran: 2000).

"Perumpamaan orang yang menginfakkan hartanya di jalan Allah seperti sebutir biji yang menumbuhkan tujuh tangkai, pada setiap tangkai ada seratus biji. Allah melipatgandakan bagi siapa yang Dia kehendaki, dan Alaah Mahaluas, Maha Mengetahui". (Q.S AlBaqarah: 126) (Yayasan Penyelenggara/Penafsir Al-Quran: 2000).

"Tidaklah hamba Allah menempuh waktu pagi mereka kecuali ada dua malaikat yang mendoakannya, salah satu dari kedua malaikat tersebut berdoa, "Ya Allah berikanlah ganti kepada orang yang berinfak" dan malaikat yang satunya berdoa "Ya Allah berikanlah kehancuran kepada orang yang kikir". (H.R Imam Bukhari dan Muslim dari Abu Hurairah r.a.)

Beberapa dalil menjelaskan bahwa sedekah memiliki makna yang lebih luas dari sekedar membayarkan sejumlah hartanya kepada orang lain (Behesti, 2014). Sedekah dalam beberapa dalil digunakan untuk segala bentuk amal baik yang berguna bagi orang lain atau bahkan diri sendiri. Sedangkan dalam PSAK 109 seperti yang telah dijelaskan diatas, infaq/shadaqoh memiliki konteks dan definisi yang sama, yakni pembayaran sukarela, baik ditentukan atau tidak peruntukannya oleh pemberi infaq/shadaqoh. 
c. Amil

Amil merupakan salah satu dari delapan golongan mustahiq yaitu orang atau badan yang berhak menerima zakat, infaq/shadaqoh. Menurut PSAK 109, amil adalah entitas pengelola zakat yang pembentukannya dan atau pengukuhannya diatur berdasarkan peraturan perundangundangan yang dimaksudkan untuk mengumpulkan dan menyalurkan zakat, infak/sedekah. Dalam PSAK 109 juga dijelaskan mengenai dana amil, yaitu bagian amil atas dana zakat dan infak/sedekah serta dana lain yang oleh pemberi diperuntukkan bagi amil. Dana amil digunakan untuk kegiatan operasional amil.

d. Model Three Circles Revitalisasi Organisasi Pengelola Zakat

Berdasarkan hasil penelitian Yulinartati, dkk. (2012) mengusulkan model pengelolaan organisasi lembaga zakat yaitu Three Circles Model. Model yang dibuat mengacu pada Lingkaran yang mempengaruhi dan dipengaruhi oleh adanya pembayaran zakat, infak dan shodaqah (ZIS). Setiap Lingkaran akan dianalisis mengenai faktor-faktor di dalamnya. Dengan demikian, diharapkan kelemahan dan kelebihan yang dimiliki oleh lembaga zakat dapat lebih mudah dianalisis. Penjelasan mengenai tiga Lingkaran tersebut akan dibahas sebagai berikut :

1) Lingkaran Pertama (Lingkaran Merah)

Lingkaran pertama menunjukkan interaksi antara amil dan muzaki baik dengan cara metode langsung maupun tidak langsung.

2) Lingkaran Kedua (Lingkaran Hijau)

Lingkaran kedua menunjukkan interaksi antara amil dan mustahiq baik dengan cara metode langsung maupun tidak langsung.

3) Lingkaran Ketiga (Lingkaran Hitam)

Lingkaran ketiga menunjukkan interaksi antara muzaki, amil, dan mustahiq baik dengan cara metode langsung maupun tidak langsung. Lingkaran ketiga menunjukkan 


\section{Nur Hisamuddin}

perlunya sinergi dengan berbagai stakeholder seperti muzaki, amil, mustahiq, pembuat kebijakan dan media massa. Jika OPZ ingin berhasil dengan baik, maka ia harus mampu membangun kepercayaan para muzaki.

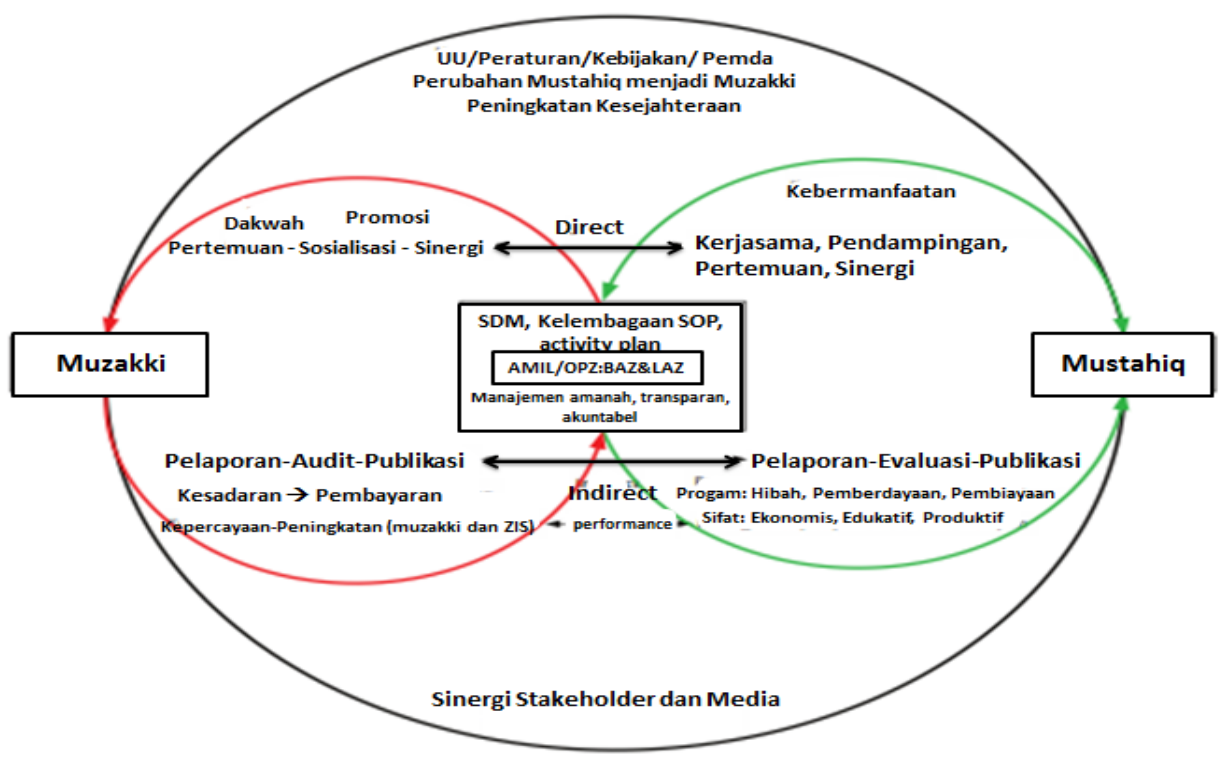

Gambar 2.2 Three Circles Revitalisasi Organisasi Pengelola Zakat (Sumber : Yulinartati, dkk. 2013)

\section{Simpulan}

Potensi zakat yang sedemikian besar menuntut pengelolaan yang professional, baik dari sisi SDM maupun Organisasi. Dana Zakat tidak hanya berhenti pada penerimaan dan penyaluran zakat saja, tetapi harus ada bentuk pertanggung jawaban seperti laporan keuangan yang akan menjadi jembatan informasi bagi semua pihak yang berkepentingan.

Keberlangsungan lembaga tidak tergantung kepada figur seseorang, tetapi kepada sistem. Akuntansi zakat mempunyai kaidah-kaidah tersendiri yang tidak terdapat pada sistem akuntansi yang selama ini sudah ada. sistem informasi akuntansi adalah suatu sistem informasi yang berisi data atau komponen baik fisik maupun non fisik yang saling berinteraksi 
Telaah Penerapan Sistem Informasi Manajemen ...

yang kemudian diolah sedemikianrupa sehingga menghasilkan informasi yang berguna bagi pihak-pihak yang berkepentingan.

\section{DAFTAR PUSTAKA}

Aditya, Erwin.2013.Optimalisasi Pengelolaan Zakat Sebagai Sarana Mencapai Kesejahteraan Sosial (Sebuah Studi Di Badan Amil Zakat Kota Semarang). Semarang : Universitas Negeri Semarang.

Andikawati, Desy.2014. Laporan Keuangan Lembaga Masjid (Studi kasus pada lembaga masjid Agung Anaz Mhfudz dan Masjid Al-Huda). Jember: Universitas Jember.

Bodnar, George H. dan Hopwood, William S. Alih Bahasa: Amir Abadi Jusuf dan M. Tambunan.2006. Sistem Informasi Akuntansi. Jakarta: Salemba Empat.

Chariri, Anis.2009. Landasan Filsafat dan Metode Penelitian Kualitatif. Paper. Semarang : Universitas Diponegoro.

IAI.2008. Pernyataan Standar Akuntansi Keuangan no. 109 : Akuntansi Zakat, Jakarta.

Indriantoro, Nur dan Supomo.2014. Metodologi Penelitian Bisnis Untuk Akuntansi \& Manajemen. Yogyakarta: BPFE Yogyakarta.

Komar,Abdul.2012. Manajemen Zakat Di BAZ Kabupaten Lumajang. Kraksaan : Institut Ilmu Keislaman Zainul Hasan.

Mulyadi.2001. Sistem Akuntansi (edisi tiga). Jakarta: Salemba Empat. 


\section{Nur Hisamuddin}

Pujianto.2015.Implementasi PSAK 109 Tentang Akuntansi Zakat dan Infak/Sedekah (Studi Empiris pada Organisasi Pengelola Zakat dan Infak/Sedekah Di Kota Semarang). Skripsi. Semarang : Universitas Negeri Semarang.

Rahma, Mivthahul.2015. Cara-Cara Konversi Sistem Informasi. Bogor: Institut Pertanian Bogor.

Sucipto, Agus.2011. Membangun Transparansi dan Akutabilitas. Malang : Universitas Islam Negeri Malang

Susanto, Azhar.2008. Sistem Informasi Akuntansi. Bandung: Lingga Jaya.

Sutopo, HB.2002. Metode Penelitian Kualitatif, Dasar Teori dan terapannya dalam penelitian. Edisi Pertama, Cetakan Pertama. Surakarta : Universitas Sebelas Maret.

Teguh, Muhammad.2005. Metodologi Penelitian Ekonomi. Jakarta: Raja Grafindo Persada.

Triyuwono, Iwan.2012. Akuntansi Syariah (Perspektif, Metodologi dan Teori). Jakarta: PT. Raja Grafindo Persada.

Yasin, Ahmad.2011. Panduan Zakat Praktis.www.zakat.id diakses pada tamggal 16 Mei 2016.

Yulinartati, dkk.2012. Three Circles Model Revitalitas Lembaga Pengelola Zakat. Penelitian Dana Hibah Bersaing. Jember : Universitas Muhammadiyah Jember.

Yulinartati, dkk.2013. Penerapan Three Circles Model Revitalisasi Lembaga Pengelola Zakat Pada LAZIZMU Di Kabupaten Jember. Jember : Universitas Muhammadiyah Jember. 
Telaah Penerapan Sistem Informasi Manajemen ...

Yayasan Penyelenggara Penterjemah/Penafsir Al-Quran.2000. Al-Quran dan Terjemahnya. Bandung : Diponegoro.

FATWA MAJELIS ULAMA INDONESIA Nomor 8 Tahun 2011. Tentang Amil Zakat. Jakarta: Komisi Majelis Ulama Indonesia.

Undang-Undang Republik Indonesia Nomor 23 Tahun 2011. Pengelolaan Zakat. Tambahan Lembaran Negara Republik Nomor 5225. Jakarta.

Universitas Jember.2016.Pedoman Penulisan Karya Ilmiah. Jember: UPT Penerbitan Universitas Jember.

Keputusan Menteri Agama Nomor 581 Tahun 1999 tentang Pelaksanaan Pengelolaan Zakat 